\title{
Corrosion inhibition and adsorption studies by Pogostemon- quadrifolius methanolic stem extract (PQMSE) on mild steel in 1M HCL
}

\author{
Jisha $M^{1 *}$, Zeinul Hukuman N. $\mathbf{H}^{1}$, Leena.P ${ }^{1}$ \\ ${ }^{1}$ Department of Post Graduate Studies and Research in Chemistry, Sir Syed College, Taliparamba, Kannur, Kerala, India, 670142 \\ *Corresponding author E-mail:jishavinayan123@gmail.com
}

\begin{abstract}
Pogostemon quadrifolius methanolic stem extract (PQMSE) has been investigated as non toxic green corrosion inhibitor for mild steel in $1 \mathrm{M} \mathrm{HCl}$. Corrosion rates were evaluated at $303 \mathrm{~K}, 313 \mathrm{~K}$ and $323 \mathrm{~K}$ by weight loss method at varying inhibitor concentrations. Using electrochemical impedence spectroscopy (EIS) and polarisation techniques, corrosion studies were done at $303 \mathrm{~K}$ in various inhibitor concentrations. Adsorption studies were also conducted to study the mechanism of corrosion inhibition. Scanning electron microscopy (SEM) and Fourier - transform infrared (FT-IR) spectroscopy were used to study the surface morphology of mild steel. Electrochemical studies reveal that PQMSE exhibit excellent corrosion inhibition efficiency and it function as a mixed type of inhibitor at $303 \mathrm{~K}$. The surface interaction of PQMSE on mild steel in $1 \mathrm{M} \mathrm{HCl}$ was obeying Langmiur adsorption isotherm at all studied temperatures.
\end{abstract}

Keywords: Pogostemon quadrifolius; Stem; Corrosion Inhibitor; Weight Loss; Electrochemical Studies; Adsorption.

\section{Introduction}

Corrosion of metals has always been an interesting topic among corrosion scientists and engineers. Mild steel hydrochloric acid system and the behaviour of corrosion inhibitors in such systems have gained great importance in the past decades. Inhibitors are used in acid solutions during acid pickling, cleaning in industries, oil - wellacidization,for removal of rust, corrosion products and scale etc (Mourya et al., 2014; Krishnegowda et al., 2013; Ji et al., 2015; Raja et al., 2013). Various organic and inorganic compounds have been investigated as effecient and effective corrosion inhibitors (Finsgar and Jackson, 2014). Many inorganic inhibitors, especially those containing chromate, phosphate and other heavy metals are banned due to their toxicity and the threat caused to aquatic ecosystems (Roy et al., 2014). Toxicity and high cost of manufacturing interrupted the extensive use of synthetic organic corrosion inhibitors. This resulted in the exploration of cheap biodegradable ecofriendly green corrosion inhibitors. Natural plant extracts are analogous to the synthetic organic inhibitors and are proven efficient as their synthetic counterparts (Chigondo and Chigondo, 2016).

Due to natural origin,non toxic nature and negligible negative impacts on aquatic ecosystems,drugs were considered as ideal corrosion inhibitorslike many plant extracts until recent years (Raja and Sethuraman,2008; Newman et al., 2003; Newman and Cragg, 2007; Harvey, 2008; Struck et al., 2008).But not all drugs are readily biodegradable and their transformation products may be equally or even more hazardous to the environment and so more studies are needed before any drugs are concluded as ecofriendly corrosion inhibitor. The possible negative impacts of pharmaceutical contaminats are still under investigation and so the suitability of a drug as a green corrosion inhibitor should be as- sessed every time (Gece, 2011). Hence natural plants extracts form a better green corrosion inhibitor. Pogostemon quadrifolius (Benth.) of Lamiaceae is a common ethnobotanically important medicinal shrub in India, Bangladesh and Myanmar, which is used as a folk medicine against chicken pox worms and also as a blood purifier (Bhatti and Ingrouille, 1997; Lansdown, 2011; Biswas et al., 2010; Padal and Chandrasekhar, 2013; Padal et al., 2013; Padal and Raju, 2013; Raju et al., 2014). The plant is well known for its antioxidant, mosquito larvicidal, antiproliferative and antimicrobial activities (Cheriyamundath et al.,2015; 2015a, 2015 b; Klika et al., 2014;Thoppil et al., 2003; Trivedi, 2006; Pushpalatha, 2015; Jisha et al., 2016; Jisha and Hukuman, 2017). The chemical constituents of P. quadrifolius, both qualitative and quantitative, have also been well studied (Jisha et al., 2016 a, Jisha et al., $2017 \mathrm{a}, \mathrm{b})$. The corrosion inhibition activity of P. quadrifoliushas not been studied so far.In the present study, the corrosion inhibition property of the methanolic extract of the stem of P. quadrifolius (PQMSE) for mild steel in $1 \mathrm{M} \mathrm{HClhas} \mathrm{been} \mathrm{reported.} \mathrm{Weight}$ loss method, electrochemical impedence spectroscopy, potentiodynamic polarization technique, FT -IR and SEM were employed.

\section{Materials and methods}

\subsection{Inhibitor preparation}

The fresh stems of P. quadrifolius were collected from Karimbam, Kannur, Kerala and authenticated from Department of Botany, University of Calicut. The collected stems were washed, shade dried for 3 weeks and made into fine powder using a mixer grinder and the powder was kept in small airtight bottles with proper labelling. Powdered stems were extracted using methanol in soxhlet 
apparatus. The extracts were then filtered and evaporated to dry, which were used as the corrosion inhibitor.

\subsection{Mild steel specimen and medium}

Mild steel of size $2 \times 1.9 \mathrm{~cm}^{2}$ having a composition of $\mathrm{C}(0.2 \%)$, Mn (1\%), S (0.2\%) P (0.3\%) and Fe $(98.75 \%)$ were used for weight loss studies. The steel specimens were rubbed well with different grades of emery paper and degreased with acetone prior to the study. They were washed well, dried and used for weight loss studies.

Test solution of $1 \mathrm{M} \mathrm{HCl}$ was prepared by diluting analytical grade $\mathrm{HCl}$ (Merck) with double distilled water.

\subsection{Weight loss method}

The corrosion inhibition activities of the extracts for mild steel in $1 \mathrm{M} \mathrm{HCl}$ was determined by weight loss measurements at $303 \mathrm{~K}$, $313 \mathrm{~K}$ and $323 \mathrm{~K}$. Mild steel specimens which were weighed previously were immersed in $50 \mathrm{ml} 1 \mathrm{M} \mathrm{HCl}$ solution containing different concentrations of inhibitor $(100 \mathrm{ppm}, 150 \mathrm{ppm}, 200 \mathrm{ppm}$ $250 \mathrm{ppm}$ and $300 \mathrm{ppm}$ ) for 6 hours. Steel specimens immersed in $1 \mathrm{M} \mathrm{HCl}$ without inhibitor was considered as blank. The immersed steel specimens were taken out after 6 hours, washed with water, cleaned with acetone, dried and weight determination was done The corrosion rate and inhibition efficiencies were determined following standard procedures (Bribri et al., 2013) with the following equations.

$$
\begin{aligned}
& \text { Corrosion rate }\left(\mathrm{C}_{\mathrm{R}}\right)=\left(\mathrm{W}_{\mathrm{b}}-\mathrm{W}_{\mathrm{a}}\right) / \mathrm{A}^{*} \mathrm{t} \\
& \text { Inhibition efficiency }(\mathrm{IE} \%)=\left[\left(\mathrm{W}_{1}-\mathrm{W}_{2}\right) / \mathrm{W}_{1}\right] * 100
\end{aligned}
$$

Where $\mathrm{W}_{\mathrm{a}}$ and $\mathrm{W}_{\mathrm{b}}$ are the weight of steel specimens after and before immersions in the corrosion media, A the area of steel specimen in $\mathrm{cm}^{2}$, $\mathrm{t}$ the time of exposure in hours, $\mathrm{W}_{1}$ the weight loss without inhibitor and $\mathrm{W}_{2}$ the weight loss with inhibitor.

\subsection{Electrochemical measurements}

The electrochemical impedance and polarisation studies were conducted using Gill AC computer controlled work station (Model 1475: ACM, UK). The experiments were conducted at $303 \mathrm{~K}$ temperature using a conventional three electrode cell assembly. Mild steel specimen with exposed surface area $1 \mathrm{~cm}^{2}$ in the investigation was the working electrode, saturated calomel and platinum foil electrodes were the reference and auxiliary electrodes. Meas- urements were taken without and with different concentrations of stem extract of P. quadrifolius as corrosion inhibitor. Inorder to attain stability, mild steel specimens were immersed in the solutions for 1 hour before measurements.

Electrochemical impedence spectroscopy (EIS ) was carried out applying a sinusoidal voltage of amplitude $10 \mathrm{mV}$ with a frequency range $10 \mathrm{kHz}$ to $0.1 \mathrm{~Hz}$. Nyquist plots represents the impedence measurements. Inhibition efficiencies were calculated using the equation

$$
\operatorname{IE}(\%)=\frac{\mathrm{R}_{\mathrm{ct}}^{*}-\mathrm{R}_{\mathrm{ct}}}{\mathrm{R}_{\mathrm{ct}}^{*}} \times 100
$$

where $\mathrm{R}^{*}{ }_{\text {ctand }} \mathrm{R}$ ct are the charge transfer resistances with and without inhibitor respectively.

Tafel plots represent potentiodynamic polarization measurements (+250 to $-250 \mathrm{mV}$ potential range with scan rate $60 \mathrm{mV} / \mathrm{min}$ ). By extrapolating the linear segments of anodic and cathodic polarization curves to corrosion potential ( $\mathrm{E}$ corr) at different inhibitor concentrations, corrosion current density ( $i_{\text {corr }}$ ) was obtained. The corrosion inhibition efficiency was evaluated from the measuredicorrvalues as,

$\operatorname{IE}(\%)=\underline{\mathrm{i}_{\text {corr }}-\mathrm{i} *_{\text {corr }}} \times 100$ $\mathrm{i}_{\text {corr }}$

where $i_{\text {corr }}$ and $i^{*}$ corr are corrosion current densities without and with the inhibitor respectively.

\section{Results and discussion}

\subsection{Weight loss method}

Table 1 provides the weight loss measurement results conducted at $303 \mathrm{~K}, 313 \mathrm{~K}$ and $323 \mathrm{~K}$. Methanolic extract of the stem of P. quadrifolius show good corrosion inhibition for mild steel in1 $\mathrm{M}$ HCl.It shows a high inhibition efficiency of $95.20 \%$ at $303 \mathrm{~K}$, $92.41 \%$ at $313 \mathrm{~K}$ and $89.30 \%$ at $323 \mathrm{~K}$ respectively at 300ppm concentration. Corrosion rates showed tremendous decrease with increase in concentration of the inhibitor and inhibition efficiency of the extract increased with concentration of inhibitor. The high inhibition efficiency of the extract at high concentration may be due to blocking of active sites against corrosion by the adsorption of inhibitor on the surface of mild steel as suggested by previous workers (Anupama et al., 2015, 2016; Fouda et al., 2017; Shukla

\begin{tabular}{|c|c|c|c|c|c|c|c|}
\hline Temperature & $\begin{array}{l}\text { Concentration of } \\
\text { plant extract in } \\
1 \mathrm{M} \mathrm{HCl}(\mathrm{ppm}) \\
\end{array}$ & $\begin{array}{l}\text { Weight of } \\
\text { steel before } \\
\text { immersion }\end{array}$ & $\begin{array}{l}\text { Weight of steel } \\
\text { after immer- } \\
\text { sion }\end{array}$ & $\begin{array}{l}\text { Weight } \\
\text { loss }\end{array}$ & $\mathbf{W}_{\mathrm{b}}-\mathbf{W}_{\mathrm{a}}$ & $\begin{array}{l}\text { Corrosion } \\
\text { rate }(\mathrm{CR} \text { in } \\
\left.\mathrm{g} / \mathrm{cm}^{2} \mathrm{~h}\right) \\
\end{array}$ & $\begin{array}{l}\text { Inhibition } \\
\text { Efficiency (IE } \\
\% \text { ) } \\
\end{array}$ \\
\hline \multirow{8}{*}{$303 \mathrm{~K}$} & Blank & 3.745 & 0.319 & 3.426 & & 0.939 & \\
\hline & 100 & 3.671 & 2.8228 & 0.8482 & 2.5778 & 0.233 & 75.24 \\
\hline & 150 & 3.711 & 3.0364 & 0.6746 & 2.7514 & 0.185 & 80.31 \\
\hline & 200 & 3.711 & 3.2067 & 0.5043 & 2.9217 & 0.138 & 85.28 \\
\hline & 250 & 3.73 & 3.408 & 0.3220 & 3.104 & 0.088 & 90.60 \\
\hline & 300 & 3.681 & 3.5166 & 0.1644 & 3.2616 & 0.045 & 95.20 \\
\hline & Blank & 3.745 & 0.319 & 3.426 & & 0.939 & \\
\hline & 100 & 3.67 & 2.7502 & 0.9198 & 2.5062 & 0.2521 & 73.15 \\
\hline \multirow{4}{*}{$313 \mathrm{~K}$} & 150 & 3.681 & 2.9417 & 0.7393 & 2.6867 & 0.2026 & 78.42 \\
\hline & 200 & 3.73 & 3.148 & 0.5820 & 2.844 & 0.1595 & 83.01 \\
\hline & 250 & 3.745 & 3.3374 & 0.4076 & 3.0184 & 0.112 & 88.10 \\
\hline & 300 & 3.712 & 3.452 & 0.260 & 3.166 & 0.0712 & 92.41 \\
\hline \multirow{6}{*}{$323 \mathrm{~K}$} & Blank & 3.745 & 0.319 & 3.426 & & 0.939 & \\
\hline & 100 & 3.71 & 2.689 & 1.021 & 2.405 & 0.2798 & 70.21 \\
\hline & 150 & 3.681 & 2.8632 & 0.8178 & 2.608 & 0.2241 & 76.13 \\
\hline & 200 & 3.731 & 3.0629 & 0.6681 & 2.7579 & 0.1831 & 80.50 \\
\hline & 250 & 3.741 & 3.2665 & 0.4745 & 2.9515 & 0.1300 & 86.15 \\
\hline & 300 & 3.689 & 3.3224 & 0.3666 & 3.0594 & 0.1004 & 89.30 \\
\hline
\end{tabular}
and Ebenso, 2011).

Table 1:Corrosion parameters for mild steel in $1 \mathrm{M} \mathrm{HCl}$ by weight loss method at different temperatures in the absence and 


\subsection{Electrochemical studies}

\subsubsection{Electrochemical impedence spectroscopic studies (EIS)}

EIS data for mild steel in $1 \mathrm{M} \mathrm{HCl}$ was determined without and with the presence of inhibitor at concentrations $100 \mathrm{ppm}, 200 \mathrm{ppm}$ and $300 \mathrm{ppm}$ at $303 \mathrm{~K}$. The results obtained are represented as Nyquist plots in Figure 1. Charge transfer resistance $\left(\mathrm{R}_{\mathrm{ct}}\right)$, provided as the diameter of the semicircle,increases with increasing inhibitor concentration.Nyquist plots obtained are not perfect semicircles. This may be due to surface inhomogenity, roughness or impurities etc (Anupama et al., 2015; Prabhu et al., 2007; Anand et al., 1965). The various impedence data such as charge transfer resistance $\left(\mathrm{R}_{\mathrm{ct}}\right)$, corrosion current density (I corr) and inhibition efficiency (IE) as obtained from Nyquist plots are provided in table 2. Table 2 clearly shows that charge transfer resistance increased with increase in concentration of PQ stem extracts. This may be due to the formation of protective film on metal solution interface due to the adsorption of the inhibitor on the most active adsorption sites (Anupama et al., 2015).

Fig. 1:

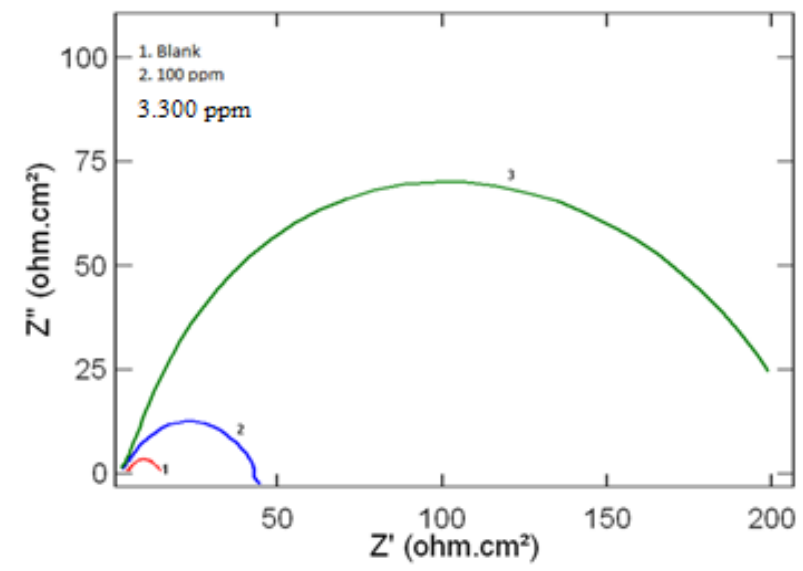

Table 2: EIS data for mild steel in $1 \mathrm{M} \mathrm{HCl}$ without and with methanolic extract of stem of $\mathrm{PQ}$

\begin{tabular}{llllll}
\hline Sample & $\begin{array}{l}\text { Concentration } \\
\text { of inhibi- } \\
\text { tor(ppm) }\end{array}$ & $\begin{array}{l}\mathrm{R}_{\mathrm{ct}} \\
\left(\Omega \mathrm{cm}^{2}\right)\end{array}$ & $\begin{array}{l}\mathrm{I}_{\text {corr }} \\
(\mathrm{mA} \\
\left.\mathrm{cm}^{2}\right)\end{array}$ & $\begin{array}{l}\mathrm{C}_{\mathrm{r}} \\
(\mathrm{mm} / \mathrm{yr})\end{array}$ & $\mathrm{IE} \%$ \\
\hline Blank & ---- & 9.256 & 2.818 & 32.67 & ------ \\
PQ stem & 100 & 41.92 & 0.623 & 7.212 & 77.91 \\
extract & 200 & 55.42 & 0.471 & 5.456 & 83.29 \\
& 300 & 194.00 & 0.135 & 1.558 & 95.21 \\
\hline
\end{tabular}

\subsubsection{Potentiodynamic polarisation studies}

The potentiodynamic polarization curves for mild steel in $1 \mathrm{M}$ $\mathrm{HCl}$ without and with PQMSE of concentration $100 \mathrm{ppm}$ and 300 ppm are shown in Figure 2. The electrochemical parameters such as corrosion potential $\left(\mathrm{E}_{\mathrm{corr}}\right)$, corrosion current density ( $\left.\mathrm{I}_{\text {corr }}\right)$, corrosion $\operatorname{rate}\left(\mathrm{C}_{\mathrm{r}}\right)$, cathodicTafel constant $\left(\beta_{\mathrm{c}}\right)$ and anodic Tafel constant $\left(\beta_{\mathrm{a}}\right)$ were determined from the polarisation curves and are provided in table 3.The inhibition efficiency(IE\%) of the PQMSE were calculated using equation 4 and provided in the table 3.It can be observed from the polarization results that the $\mathrm{I}_{\text {corr }}$ values decrease considerably in the presence of PQMSE from $100 \mathrm{ppm}$ to 300ppm.Addition of PQMSE slightly modifies the Tafel slopes. In the presence of $100 \mathrm{ppm}$ and 300ppm PQMSE in $1 \mathrm{M} \mathrm{HCl}$, no definite trend was observed in the shift of $\mathrm{E}$ corr values. Thus it may be concluded that PQMSE exhibit cathodic and anodic inhibition showing relatively mixed type of inhibition behaviour in 1 $\mathrm{M} \mathrm{HCl}$.The trend in inhibition efficiency obtained in EIS studies is in agreement with potentiodynamic polarization studies.

Fig. 2:

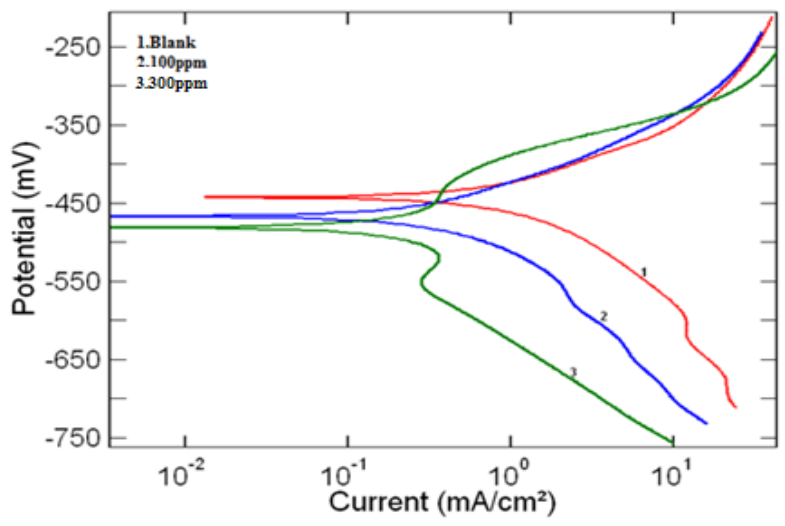

Table 3:Polarisation data for mild steel in $1 \mathrm{M} \mathrm{HCl}$ without and with methanolic extracts of stem of $\mathrm{PQ}$

\begin{tabular}{llllllll}
\hline Sample & Concentrationof inhibitor $(\mathrm{ppm})$ & $\mathrm{E}_{\text {corr }}(\mathrm{mV})$ & $\beta_{\mathrm{a}}(\mathrm{mV} / \mathrm{dec})$ & $\begin{array}{l}\beta_{\mathrm{c}} \\
(\mathrm{mV} / \mathrm{dec})\end{array}$ & $\mathrm{I}_{\text {corr }}(\mathrm{mA} \mathrm{cm})$ & $\mathrm{C}_{\mathrm{r}}(\mathrm{mm} / \mathrm{yr})$ & $\mathrm{IE} \%$ \\
\hline Blank & & -443 & 117 & 173 & 1.662 & 19.262 \\
PQ stem extract & 100 & -467 & 97.00 & 127 & 0.471 & 5.434 \\
& 300 & -482 & 71 & 146 & 0.126 & 71.60 \\
& & &
\end{tabular}

\subsection{Adsorption studies and thermodynamic parameters}

Metal - inhibitor interaction is due to adsorption of an organic molecule on the metal surface, which is a replacement reaction and it can be well studied by analysing the adsorption process using adsorption isotherms $(\mathrm{Li}, 2011)$.The surface interaction of PQMSE on mild steel in $1 \mathrm{M}$ HClwas obeying Langmiur adsorp- tion isotherm at all temperatures (303K, $313 \mathrm{~K}$ and $323 \mathrm{~K})$. Langmuir adsorption isotherm is described by the equation

$\mathrm{C}_{\mathrm{inh}} / \theta=1 / \mathrm{K}_{\mathrm{ads}}+\mathrm{C}_{\mathrm{inh}}$

where $\mathrm{C}_{\text {inh }}$ represent the concentration of the inhibitor, $\mathrm{K}_{\mathrm{ads}}$ is the equilibrium constant of adsorption process and $\theta$ the surface coverage. Figure 3 represent the Langmuir adsorption isotherm which is found to be linear. In the present study the value of correlation 
coefficient $\left(\mathrm{R}^{2}\right)$ was obtained close to unity for Langmuir adsorption isotherm.

The free energy of adsorption ( $\Delta \mathrm{G}_{\text {ads }}$ ) can be calculated using the equation

$$
\Delta \mathrm{G}_{\text {ads }}=-\mathrm{RT} \ln \left(1000 * \mathrm{~K}_{\text {ads }}\right)
$$

where $\mathrm{K}_{\text {ads }}$ is the adsorption equilibrium constant.From table 4 , it can be identified that $\Delta \mathrm{G}_{\text {ads }}$ values are negative, which is an indication of the spontaneity of adsorption and it shows the stability of adsorbed layer on mild steel surface (Keles et al., 2008; Fouda et al., 2009). It is said that the values of $\Delta \mathrm{G}$ ads obtained around -20 $\mathrm{kJ} / \mathrm{mol}$ or lower indicate physisorption whereas the values around $-40 \mathrm{~kJ} / \mathrm{mol}$ indicate chemisorption (Ahamad et al., 2010; Ozcan et al., 2008; Noor and Al- Moubaraki, 2008). Regarding an organic molecule, the adsorption phenomenon cannot be considered as purely physical or chemical adsorption (Solmaz, 2010; Doner et al., 2011). In the present investigation the value of $\Delta \mathrm{G}$ ads was between $-20 \mathrm{kJmol}^{-1}$ and $-40 \mathrm{kJmol}^{-1}$. Hence the adsorption of inhibitor on to the mild steel surface may involve both physisorption and chemisorption (Mohan et al., 2016).

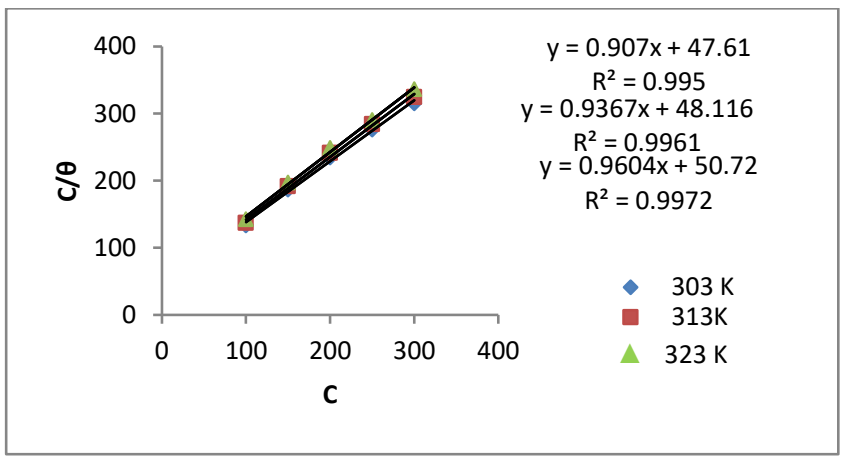

Fig. 3: Langmuir adsorption isotherm at different tempertatures for mild steel in $1 \mathrm{M} \mathrm{HCl}$ with different concentrations of methanol stem extracts of Pogostemonquadrifolius (PQMSE).

Table 4:Thermodynamic parameters calculated for the adsorption of PQMSE as inhibitor on mild steel surface in $1 \mathrm{M} \mathrm{HCl}$ at different temperatures.

\begin{tabular}{llll}
\hline & $\begin{array}{l}\text { Temperature } \\
(\mathrm{K})\end{array}$ & $\mathrm{K}_{\text {ads }}\left(\mathrm{Lg}^{-1}\right)$ & $\Delta \mathrm{G}_{\text {ads }}\left(\mathrm{Kjmol}^{-1}\right)$ \\
\hline PQM stem & 303 & 21.00 & 25.07 \\
extract & 313 & 20.28 & 26.81 \\
& 323 & 19.72 & 26.56 \\
\hline
\end{tabular}

\subsection{Scanning electron microscopy}

Scanning electron microscopic studies were conducted to study the surface morphology of the metal prior to and after immersion in $1 \mathrm{M} \mathrm{HCl}$ with and without the PQM stem extract (300 ppm). The results obtained are presented in Fig. 4, 5, and 6. Mild steel immersed in $1 \mathrm{M} \mathrm{HCl}$ in the absence of PQMSE (Fig 5) reveal clear pits and cavities indicating severe damage by the acidic media.But such corrosion pits and cavities were absent on mild steel specimen which was immersed in $1 \mathrm{M} \mathrm{HCl}$ containing PQMSE (Fig 6) and is very much similar to the mild steel specimen before immersion in acidic solution (Fig 4). Thus it proves the idea that the extract forms a protective film on the mild steel acting as a barrier preventing the corrosion activity by acidic solutions.

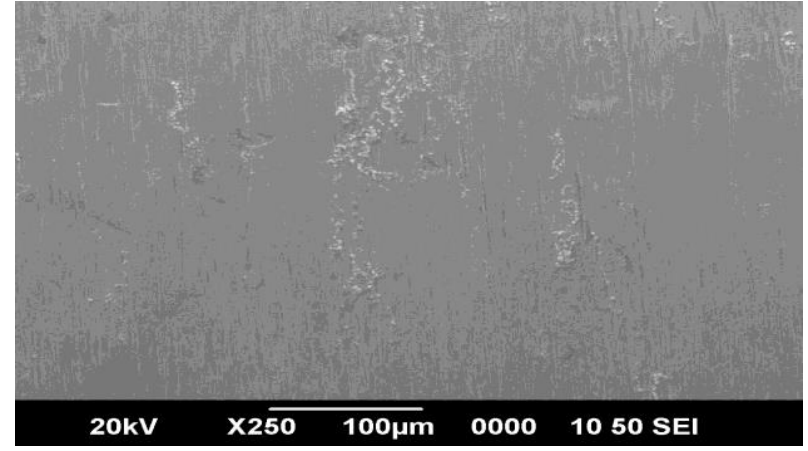

Fig. 4:SEMimage of polished mild steel before immersion in test solution.

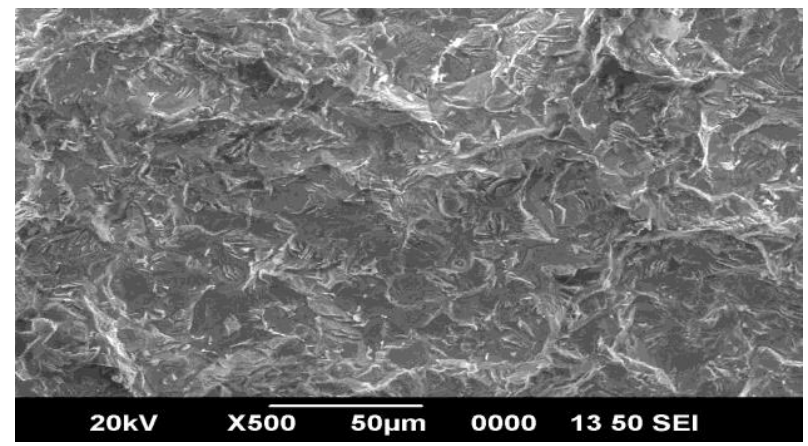

Fig. 5: SEM image of mild steel after immersion in 1M HCL without PQMSE.

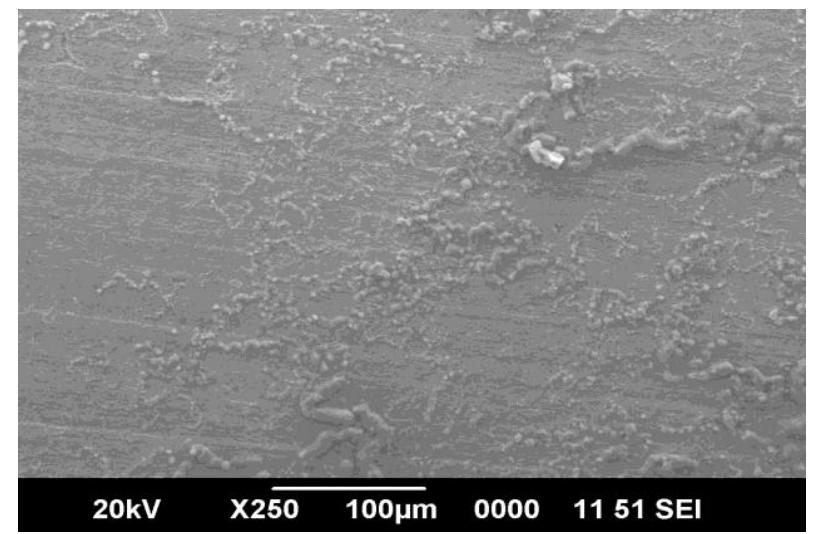

Fig. 6: SEM image of mild steel after immersion in $1 \mathrm{M} \mathrm{HCl}$ with PQMSE 300ppm.

\subsection{FTIR ( Fourier transform infrared spectroscopy)}

Inorder to identify the functional groups present in the extract FT IR analysis was carried out and that of the corrosion product was done to confirm that the inhibition takes place due to the interaction between the metal and the extract. Table 5 and 6 shows the various bonds present in the extract and the corrosion product. There is a shift in the spectra of the extract when mild steel was immersed in it to form corrosion product. This shows that there is an interaction between extract and mild steel substrate which resulted inhibition. The absorption band at $3340.22 \mathrm{~cm}^{-1}$ indicates OH stretching vibration. The peak at $2900 \mathrm{~cm}^{-1}$ indicates $-\mathrm{C}-\mathrm{H}$ stretching vibration. The absorption band at $1453.26 \mathrm{~cm}^{-1}$ corresponds to $\mathrm{C}-\mathrm{H}$ bending mode of $\mathrm{CH}_{2}$. The absorption band $1400-$ $1600 \mathrm{~cm}^{-1}$ indicates C-C vibration, band at 1267.53 indicates C-N stretching vibration. The absorption band in the range above $600 \mathrm{~cm}^{-1}$ are assigned to the $-\mathrm{C} \equiv \mathrm{C}-\mathrm{H}$ : $\mathrm{C}-\mathrm{H}$ bending vibration. The band at $1027 \mathrm{~cm}^{-1}$ indicates $\mathrm{C}-\mathrm{O}$ stretching vibration. Somefunctional groups were missing in the spectra of the corrosion product, suggesting that the absorption ofthe inhibitor on the surface of the mildsteel might have occured through the missing bands. 
Table 5:IRspectra of PQMS extract

\begin{tabular}{ll}
\hline Wave number $\left(\mathrm{cm}^{-1}\right)$ & Assignment/ vibration mode \\
\hline 3340.22 & O-H stretching \\
2900 & C-H stretching \\
1597.92 & C=C \\
1453.26 & C-H bending \\
1267.53 & C-N stretching \\
1027 & C-O stretching \\
\hline
\end{tabular}

Table 6: IR spectra of corrosion product

\begin{tabular}{ll}
\hline Wave number $\left(\mathrm{cm}^{-1}\right)$ & Assignment/ vibration mode \\
\hline 3271.58 & $\mathrm{O}-\mathrm{H}$ stretching \\
1622.05 & $\mathrm{C}=\mathrm{C}$ vibration \\
619.44 & $\mathrm{C} \equiv \mathrm{C}-\mathrm{H}, \mathrm{C}-\mathrm{H}$ bending \\
\hline
\end{tabular}

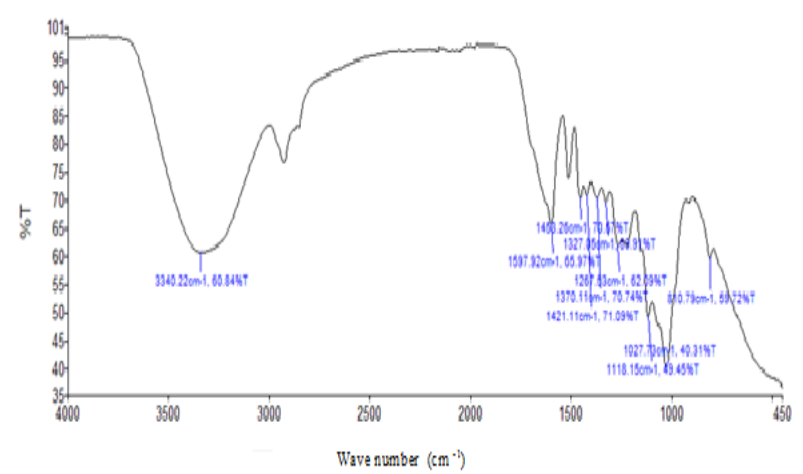

Fig. 7:FT IR spectra of crude plant extract.

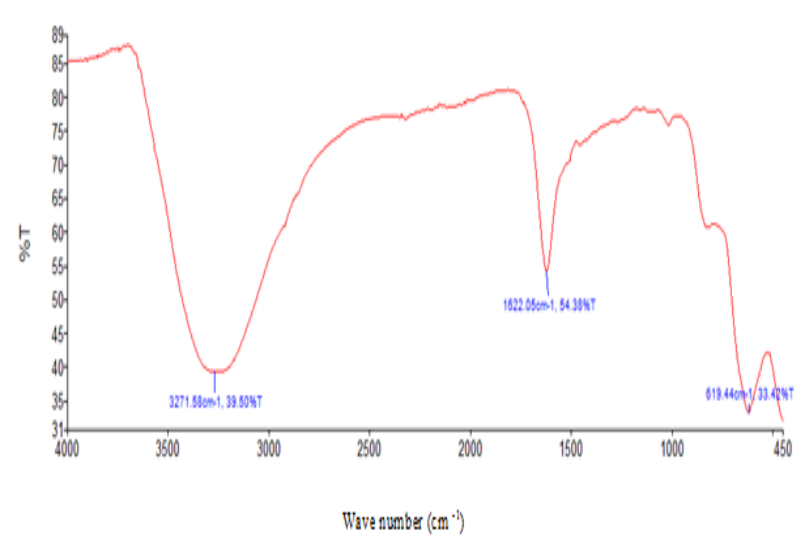

Fig. 8:FT IR spectra of the corrosion product.

\section{Conclusion}

1) Pogostemonquadrifoliusmethanolic stem extracts (PQMSE) act as a good corrosion inhibitor for mild steel in $1 \mathrm{M} \mathrm{HCl}$.

2) Weight loss studies strongly suggest the protective barrier formation by PQMSE on mild steel surface, whichis supported by SEM studies and FT-IR studies.

3) Results obtained from EIS studies and potentiodynamic polarisation studies are in good agreement showing high inhibition efficiency by PQMSE on mild steel surface in $1 \mathrm{M}$ $\mathrm{HCl}$.

4) Polarisation technique reveals the mixed type inhibition nature of PQMSE.

5) The surface interaction of PQMSE on mild steel in $\mathrm{M} \mathrm{HCl}$ was obeying Langmiur adsorption isotherm.

\section{Acknowledgements}

The first author is grateful to Kannur University for awarding a Junior Research Fellowship and the authors are grateful to Prof. Dr.Abraham Joseph, Department of Chemistry, University of Calicut for the facilities provided. The authors are also thankful to the
Principal and Head, Department of PG studies and Research in Chemistry, Sir Syed College, Taliparamba for facilities.

\section{Conflict of interest}

The authors declare that there are no known conflicts of interest associated with this publication. We confirm that the manuscript has been read and approved by all the authors and the order of authors listed in the manuscript has been approved by all.

\section{References}

[1] Ahamad I, R. Prasad and M.A. Quraishi (2010). Thermodynamic, electrochemical and quantum chemical investigation of some Schiff bases as corrosion inhibitors for mild steel in hydrochloric acid solutions, Corros.Sci.52:933-942.

https://doi.org/10.1016/j.corsci.2009.11.016.

[2] Anand R.R, R.M.Hurd and N. Hackerman (1965). Adsorption of monomeric and polymeric amino corrosion inhibitors on steel. J.Electrochem.Soc.112:138- 144. https://doi.org/10.1149/1.2423482.

[3] Anupama K.K, K Ramya and A. Joseph (2016). Electrochemical and computational aspects of surface interaction and corrosion inhibition of mild steel in hydrochloric acid by Phyllanthus amarusleafextract(PAE). Journal of Mol. Liquids 216: 146 - 155 https://doi.org/10.1016/j.molliq.2016.01.019.

[4] Anupama KK, K Ramya, KM Shainy and A. Joseph (2015). Adsorption and electrochemical studies of Pimenta dioica leaf extracts as corrosion inhibitor for mild steel in hydrochloric acid.Mater. Chem.Phys. 167:28-41. https://doi.org/10.1016/j.matchemphys.2015.09.013

[5] Bhatti, G.R. and M. Ingrouille (1997).Systematics of Pogostemon (Labiatae). Bull. Nat. Hist. Mus. Bot. Ser., 27: 77-147.

[6] Biswas, A., M.A. Bari, M. Roy and S.K. Bhadra (2010). Inherited folk pharmaceutical knowledge of tribal people in the Chittagong hill tracts, Bangladesh. Indian J. Tradit. Knowledge, 9: 77-89.

[7] Bribri A. El, M.Tabyaoui, B. Tabyaoui, H.El.Attari and F. Bentiss (2013). The use of Euphorbia falcata extract as eco -friendly corrosion inhibitor of carbon steel in hydrochloric acid solution. Mater Chem.Phys.141(1):240-247.

https://doi.org/10.1016/j.matchemphys.2013.05.006

[8] Cheriyamundath, S., R. Raghavan and J. Madassery (2015). DPPH Radical scavenging property of Methanol leaf extract from Pogostemon quadrifolius(Benth.). Res. Jour.of Med. Plants 9 (7): 361367. https://doi.org/10.3923/rjmp.2015.361.367.

[9] Cheriyamundath, S., R. Raghavan, K.B. Megha and J. Madassery (2015 a). Cytotoxic effectof Ethylidene-4, 6- Dimethoxycoumaran3-one from Pogostemon quadrifolius(Benth.).on prostate cancer cell line. Proceedings of the $27^{\text {th }}$ Kerala Science Congress. p.26.

[10] Cheriyamundath, S., R. Raghavan, K.B. Megha and J. Madassery (2015 b). (Z)-Ethylidene-4, 6-dimethoxycoumaran-3-one induces apoptosis in chronic myelogenous leukemia cell line. Int. J. Biol. Chem., 9: 86-91. https://doi.org/10.3923/ijbc.2015.86.91.

[11] Chigondo M and F. Chigondo (2016). Recent natural corrosion inhibitors for mild steel: An overview. JournalofChemistry.1-7. https://doi.org/10.1155/2016/6208937.

[12] Doner A., R. Solmaz, M. Ozcan and G. Kardas (2011). Experimental and theoretical studies of thiazoles as corrosion inhibitors for mild steel in sulphuric acid solution. Corros. Sci. 53: 2902 2913. https://doi.org/10.1016/j.corsci.2011.05.027.

[13] Finsgar M and J Jackson (2014). Application of corrosion inhibitors for steels in acidic media for the oil and gas industry. A review. Corros.Sci. 86: 17 - 41.https://doi.org/10.1016/j.corsci.2014.04.044

[14] Fouda AS, AS Abousalem and GY El. Ewady (2017). Mitigation of corrosion of carbon steel in acidic solutions using an aqueous extract of Tilia cordata as green corrosion inhibitor. Int. J. Ind. Chem. 8: 61 - 73. https://doi.org/10.1007/s40090-016-0102-z.

[15] Fouda A.S., F.E. Heakal and M.S. Radwan (2009). Role of some thiadiazole derivatives as inhibitors for the corrosion of C-steel in 1 $\mathrm{MH}_{2} \mathrm{SO}_{4}$.J.Appl.Electrochem.39:391-402. https://doi.org/10.1007/s10800-008-9684-2.

[16] Gece. G (2011). Drugs: a review of promising novel corrosion inhibitors.CorrosSci.53:3873-3898. https://doi.org/10.1016/j.corsci.2011.08.006.

[17] Harvey A.L (2008).Natural products in drugdiscovery. Drug Discov Today. 13: 894 -901.https://doi.org/10.1016/j.drudis.2008.07.004.

[18] Ji G, Anjum S, Sundaram.S. In addition,Prakash R (2015). Musa paradisica peel extract as green corrosion inhibitor for mild steel in 
HClsolution Corros.Sci.90:107-117.

https://doi.org/10.1016/j.corsci.2014.10.002.

[19] Jisha M, NH ZeinulHukuman and P Leena (2016 a). GC - MS analysis of leaves and flowers of Pogostemon quadrifolius(Benth.) F. Muell. (Lamiaceae). World J. Pharm. Res. 5 (12):667 - 681.

[20] Jisha M, NH ZeinulHukuman and P Leena (2016 b). In vitro antimicrobial activities of the leaves and flowers of Pogostemonquadrifolius(Benth.) F. Muell. (Lamiaceae). Eur. J. Biomed. Pharm. Sci. 3 (12): $553-559$.

[21] Jisha M and NH ZeinulHukuman (2017). In vitro antioxidant efficacy of the flowers and leaves of Pogostemon quadrifolius(Benth.) F. Muell. (Lamiaceae). Der PharmaChemica 9 (8):21 - 24

[22] Jisha M, NH ZeinulHukuman and P Leena (2017 a). Preliminary phytochemical screening and quantitative estimation of total flavonoids and phenols in the leaves and flowers of Pogostemon quadrifolius(Benth.) F. Muell. (Lamiaceae). Proceedings of the 104 th Indian Science Congress (Chemical Sciences).Thirupathi, Andhra Pradesh. 223- 224

[23] Jisha M, NH ZeinulHukuman and P Leena (2017 b).Quantitative analysis of selected secondary metabolites in the leaves and flowers of Pogostemon quadrifolius(Benth.) F. Muell. (Lamiaceae). Int. J. ChemTech. Res. 10 (2): $1079-1084$

[24] Keles H., M. Keles, I. Dehri and O. Serindag (2008). Adsorption and inhibitive properties of aminobiphenyl and its Schiff base on mild steel corrosion in $0.5 \mathrm{M} \mathrm{HCl}$ medium, Colloids Surf. A Physicochem.Eng.Asp.320:138-145. https://doi.org/10.1016/j.colsurfa.2008.01.040

[25] Klika, K.D., S. Cheriyamundath, R. Raghavan, K.B. Megha, A. Banerji, R.W. Owen andJ. Madassery (2014). Ethylidene-4, 6dimethoxycoumaran-3-one: The $\mathrm{C} 2=\mathrm{C} 8$ double bond configuration.TetrahedronLett 55:6550-6553. https://doi.org/10.1016/j.tetlet.2014.10.008

[26] Krishnegowda P M, Venkatesha V T, Kumar M.K.P, and Shivayogiraju S. B (2013).Acalypha torta leaf extract as green corrosion inhibitor for mild steel in hydrochloric acid solution. Ind. Eng. Chem. Res 52: 722 - 728. https://doi.org/10.1021/ie3018862.

[27] Lansdown, R.V (2011).Pogostemon quadrifolius. The IUCN Red ListofThreatenedSpecies,Version2014.3. http://www.iucnredlist.org/details/classify/199696/0

[28] Li X, Deng S and Fu H (2011). Triazolyl blue tetrazolium bromide as a novel corrosion inhibitor for steel in $\mathrm{HCl}$ and $\mathrm{H} 2 \mathrm{SO} 4$ solutions. CorrosSci 53: 302 -309.https://doi.org/10.1016/j.corsci.2010.09.036.

[29] Mohan, R., K.Ramya, K.K Anupama and Abraham Joseph (2016). Density functional treatment and electro analytical measurements of liquid phase interaction of 2 - ethylbenzimidazole (EBI) and ethyl ( 2 -ethylbenzimidazolyl) acetate (EEBA) on mild steel in hydrochloric acid. JournalofMol liquids, 220:707 717.https://doi.org/10.1016/j.molliq.2016.04.113.

[30] Mourya P., Banerjee S and Singh M. M (2014). Corrosion inhibition of mild steel in acidic solution by Tagetes erecta(Marigold flower) extract as a green inhibitor. Corros.Sci 85: 352 - 363. https://doi.org/10.1016/j.corsci.2014.04.036.

[31] Newman D.J and G.M. Cragg (2007). Natural products as source of new drugs over the last 25 years. J. Nat. Prod. 70:461 477.https://doi.org/10.1021/np068054v

[32] Newman D.J, G.M Cragg and K.M Snader (2003). Natural products as sources of new drugsover the period $1981-2002$. J. Nat. Prod 66: 1022 - 1037.https://doi.org/10.1021/np0300961.

[33] Noor E.A.and A.H. Al-Moubaraki (2008). Thermodynamic study of metal corrosion and inhibitor adsorptionprocess in mild steel/1methyl-4[4' (-X)-styrylpyridinium iodides/hydrochloric acid systems.Mater.Chem.Phys.110:145-154 https://doi.org/10.1016/j.matchemphys.2008.01.028.

[34] Ozcan M., R. Solamaz, G. Kardas and I. Dehri (2008). Adsorption properties of barbiturates asgreen corrosion inhibitors on mild steel in phosphoric acid, Colloids Surf. A Physicochem. Eng. Asp. 325: 57-63.https://doi.org/10.1016/j.colsurfa.2008.04.031.

[35] Padal, S.B. and J.B. Raju (2013). Ethnomedicinal plants used by tribals of Rayagadda district, Odisha state, India. Int. J. Innov. Res. Dev., 2: 1299-1309.

[36] Padal, S.B. and P. Chandrasekhar (2013).Ethnomedicinal use of herb species Khammam district, Andhra Pradesh, India. J. Innov. Res. Dev., 2: 1287-1298.

[37] Padal, S.B., P. Chandrasekhar and Y. Vijayakumar (2013). Traditional uses of plants by the tribal communities of SaluguPanchayat of Paderu Mandalam,Visakhapatnam, District, Andhra Pradesh, India. Int. J. Comput. Eng. Res., 3: 98-103.

[38] Prabhu R.A, A.V. Shanbag and V.T.Venkatesha (2007). Influence of tramadol [2- [(dimethylamino) methyl]-1-(3-methoxyphenylcy

clohexanolhydrate] on corrosion inhibition of mildsteel in acidic media. J.Appl. Electrochem 37: 491 -497.

[39] Pushpalatha E (2015).Acute toxicity of two tropical plant extracts onthe fecundity and fertility of Culexquinquefaciatus Say. Adv. Zool. Bot. 3 (3): $38-41$.

[40] Raja P.B ,Fadaeinasab M, Qureshi A.K, Rahim A.A, Osman H, Litaudon .M and Awang. K (2013).Evaluation of green corrosion inhibition by alkaloid extracts of Ochrosia oppositifolia and Isoreser piline against mild steel in $1 \mathrm{M} \mathrm{HCl}$ medium. Ind. Eng. Chem .Res 52:10582 - 10593.https://doi.org/10.1021/ie401387s

[41] Raja P.B and Sethuraman M G (2008). Natural products as corrosion inhibitor for metals in corrosive media. A review Mater.Lett. 62 113 - 116.https://doi.org/10.1016/j.matlet.2007.04.079.

[42] Raju, Y.R., P. Yugandhar and N. Savithriamma (2014). Documenta tion of ethnomedicinal knowledge of hilly tract areas of east Godavri district of Andhra pradesh, India. Int. J. Pharm. Pharm. Sci., 6: 369374.

[43] Roy P., P.Karfa, U. Adhikari and D.Sukul (2014). Corrosion inhibi tion of mild steel in acidic medium by polyacrylamide grafted Guar gum with various grafting percentage: effect of intramolecular synergism.Corros.Sci.88:246-253.

https://doi.org/10.1016/j.corsci.2014.07.039.

[44] Shukla SK and EE Ebenso (2011). Corrosion inhibition, Adsorption behaviour and thermodynamic properties of Streptomycin on mild steel in Hydrochloric acid medium. International Journal of Elec trochemical Science, 6: 3277 - 3291.

[45] Solmaz R (2010). Investigation of the inhibition effect of 5-((E)-4 phenylbuta-1, 3- dienylideneamino) 1, 3, 4-thiadiazole-2-thiol

Schiff base on mild steel corrosion in hydrochloric acid.Corros.Sci. 52:3321-3330. https://doi.org/10.1016/j.corsci.2010.06.001. [46]Struck S, U Schmidt, B. Gruening, IS Jaeger, J Hossbach and R Preissner (2008). Toxicity vs potency: Elucidation of toxicity prop erties discriminating between toxins, drugs and natural compounds Genome inform. 20: 231 -242.

[47] Thoppil, J.E., J. Minija, A. Tajo and M.J. Deena (2003). Antimi crobial activities of Eusteralis deccanensis and E. quadrifolia essential oils. J. Environ. Biol., 24: 211-212.

[48] Trivedi, P.C (2006). Medicinal Plants: Traditional Knowledge. I.K International Pvt. Ltd., India, 258 pp. 